\title{
Primary Cutaneous Diffuse Large B-Cell Lymphoma with Tongue Involvement
}

Satoshi Kayukawa', Takae Kataoka', Tomoko Nishio², Takashi Kanamori'1, Takaki Kikuchi'1, Ryuichi Furuta ${ }^{3}$ and Kenji Ina ${ }^{3 *}$

${ }^{1}$ Department of Clinical Oncology, Nagoya Memorial Hospital, Nagoya, Japan

${ }^{2}$ Department of Pathology, Nagoya Memorial Hospital, Nagoya, Japan

${ }^{3}$ Department of Medical Oncology, Nagoya Memorial Hospital, Nagoya, Japan

\begin{abstract}
We report a case of diffuse large B-cell lymphoma involving the thigh skin and tongue in an 85-year-old woman. No systemic symptoms or other lesions were observed at diagnosis. Local radiotherapy was effective, but cutaneous recurrence occurred 6 months after the treatment. The patient died of old age with no macroscopically distinguishable nodal or systemic lesions. A postmortem examination revealed intravascular invasion into the tongue, lung, and lymph nodes around the pancreas. To our knowledge, this is the first report of primary cutaneous diffuse large B-cell lymphoma with tongue involvement.
\end{abstract}

Keywords: Primary cutaneous lymphoma; Diffuse large B-cell lymphoma; Tongue

\section{Introduction}

A variety of $\mathrm{T}$ - and B-cell neoplasm can involve the skin and the term "primary cutaneous lymphoma" refers to the disorder that present in the skin with no evidence of extracutaneous disease at the time of diagnosis [1,2]. Among them, primary cutaneous diffuse large B-cell lymphoma, leg type (PCDLBCL, LT) is characterized with skin lesions on one or both legs. In patients presenting with a single small skin tumor, radiotherapy should be considered [2,3]. Although nonHodgkin'sB-cell lymphoma represents the second leading malignancy of oral cavity, lymphoma involving the tongue is very rare [4,5].

We herein describe a case of PCDLBCL, LT with tongue involvement successfully treated with local radiotherapy.

\section{Case Report}

An 85-year-old woman was admitted with pruritic, erythematous, and scaly plaques on her left thigh. This lesion diagnosed as diffuse large B-cell lymphoma (DLBCL) by skin biopsy (Figure 1) was slowly

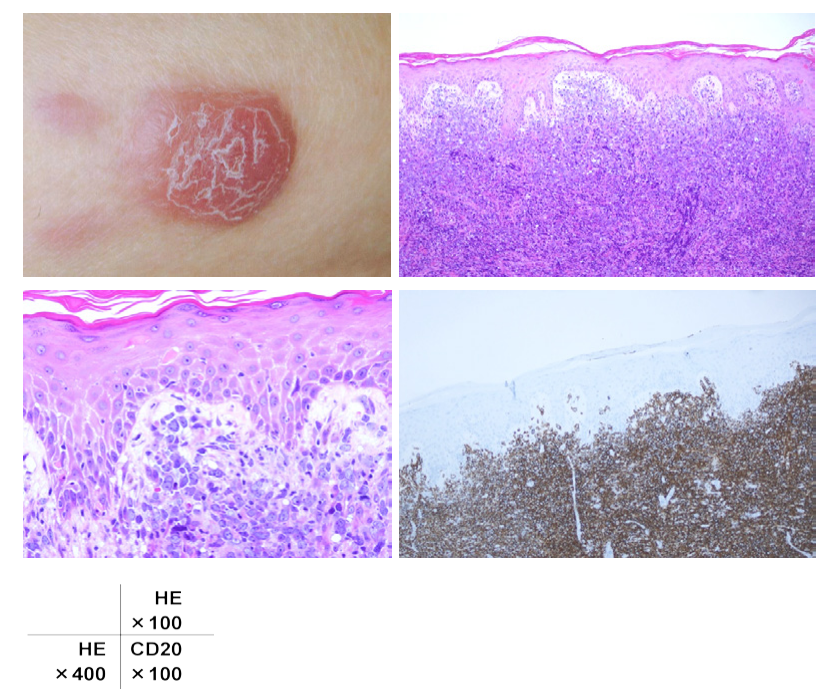

Figure 1: Cutaneous tumor of the thigh. Diffuse subcutaneous infiltration of atypical lymphoid cells with evident nucleoli was observed in the punch biopsy sample. These cells were positive for cell surface CD20 immunostaining. $\mathrm{HE}$ : Hematoxylin and Eosin Staining progressing during 3 months without systemic signs or symptoms. Staging evaluation for systemic disease by peripheral blood examination, bone marrow aspiration, and computed tomography (CT) scan was negative. Gallium scintigraphy suggested a nasopharynx lesion (Figure 2); however, otolaryngologists did not find any abnormality in the patient's oral cavity. The provisional diagnosis was PCDLBCL, LT.

Because the patient had already been bedridden at the time of initial diagnosis, systemic chemotherapy was not chosen, and local radiotherapy for the thigh tumor was started. Subsequently, we recognized an indurated submucosal nodule on the lingual apex,

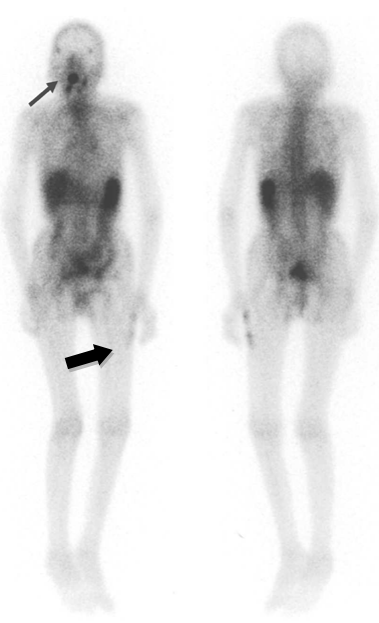

Figure 2: Gallium scintigraphy showing a cutaneous tumor (lower arrow) and suggesting a nasopharynx lesion (upper arrow).

*Corresponding author: Kenji Ina, Department of Medical Oncology, Nagoya Memorial Hospital, 4-305 Hirabari, Tenpaku-ku, Nagoya 468-8520, Japan, Tel: +81-52-804-1111; Fax: +81-52-803-8830; E-mail: kina@hospy.or.jp

Received December 05, 2013; Accepted January 25, 2014; Published January 27, 2014

Citation: Kayukawa S, Kataoka T, Nishio T, Kanamori T, Kikuchi T, et al. (2014) Primary Cutaneous Diffuse Large B-Cell Lymphoma with Tongue Involvement. J Clin Case Rep 4: 339. doi:10.4172/2165-7920.1000339

Copyright: (c) 2014 Kayukawa S, et al. This is an open-access article distributed under the terms of the Creative Commons Attribution License, which permits unrestricted use, distribution, and reproduction in any medium, provided the original author and source are credited. 

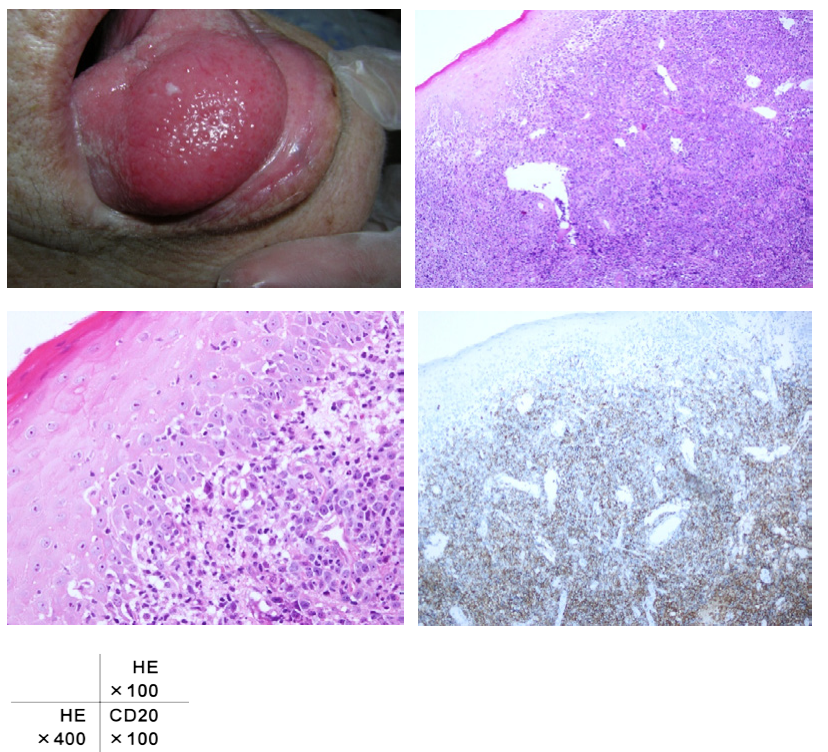

Figure 3: Biopsy specimens obtained from the tongue tumor had similar histological findings to the cutaneous lesion. Diffuse CD20-expressing lymphoma cells infiltrated the subepithelial layer.

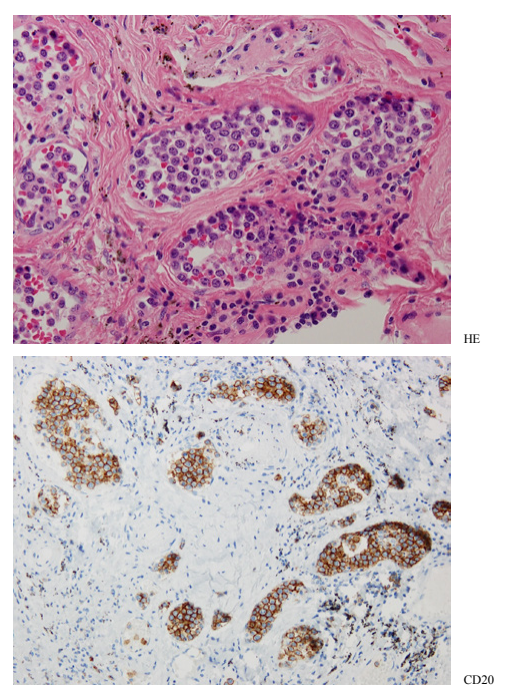

Figure 4: CD20-positive small round cells were localized to the intravascular space in the areas of invasion.

which grew up to $2 \mathrm{~cm}$ during the first two weeks of radiation and caused difficulty in mastication. Biopsy specimens obtained from the tongue tumor had similar histological findings to the cutaneous lesion (Figure 3). The atypical lymphoid cells were positive for CD19, CD20, and CD25 and negative for CD3 by immunohistochemistry. Radiation therapy was also initiated for the tongue lesion. Both skin and tongue lesions responded well to local radiotherapy with 40 Gy and $36 \mathrm{~Gy}$, respectively, and subsequently disappeared. The patient developed a subcutaneous tumor in the left inguinal region within 6 months after the treatment. The recurrent skin lesion was treated with fractionated radiation therapy and resolved completely.

Ten months after the initial diagnosis, the patient was readmitted to the hospital due to dysphagia. No relapse was observed in the oral cavity or pharynx; however, the patient became weak and eventually died of old age. A postmortem examination revealed no evidence of lymphadenopathy or any other macroscopic lesions. However, microscopic examination revealed invasion into the tongue, lung, and lymph nodes around the pancreas. Small round cells were localized in the intravascular space (Figure 4) in the invasive areas, contrast to the findings of previous biopsy specimens. CD20-positive large cells were found to proliferate, so we diagnosed these lesions as lymphoma invasion.

\section{Discussion}

Primary cutaneous B-cell lymphoma belongs to a group of B-cell lympho-proliferative disorders that are localized to theskin and show no evidence of extracutaneous manifestation at the time of initial diagnosis [1]. PCDLBCL, LT is an aggressive B-cell lymphoma that accounts for only $1-3 \%$ of all cutaneous lymphoma cases and approximately $10-20 \%$ of PCBCL cases [2]. Skin lesions are either solitary or multiple, with a predilection for the lower extremities and/or trunk. This disorder predominantly affects elderly patients, particularly women, often disseminates to extracutaneous sites, and has less favorable prognosis [3].

The head and neck is the second most common region for extranodal lymphoma after the gastrointestinal tract [4]. Although Waldeyer's ring lymphomas account for $50-80 \%$ of all head and neck lymphoma cases, lymphoma of the tongue is rare [5-8]. Sato reported a series of 21 cases of non-tonsillar oral diffuse large cell lymphoma, which included only one case with tongue involvement, showing favorable prognosis after cyclophosphamide, doxorubicin, vincristine, and prednisone (CHOP)-like chemotherapy and/or radiation [9]. Cutaneous-tongue manifestation is very rare $[10,11]$ and only three cases being reported in the literature (Table 1). While all reported cases were of cutaneous T-cell lymphomas, our case was diagnosed as PCDLBCL, LT. The patient presented with extranodular lesions in the skin and tongue, and multiorgan involvement was not observed until her death. Histological findings on postmortem examination showed that the tumor cells were localized to the vessels and formed clusters, similar to the findings in intravascular large B-cell lymphoma (IVLBCL) [12]. It has been reported that IVLBCL is pathologically distinct with a broad clinical spectrum beyond immunophenotypic diversity and comprises a unique group with aggressive behavior such as hemophagocytic syndrome and neurologic signs [13]. These symptoms result from occlusion of small vessels by neoplastic cells in a variety of organs. In Western countries, cutaneous lesions are also well known as one of the main clinical manifestations of IVLBCL. However, it is unlikely that the relapsed very small lesions observed on postmortem examination of our patient could result in her death.

In conclusion, we believe that this was a case of PCDLBCL, LT, which initially grew relatively slowly and responded well to the local

\begin{tabular}{|l|l|l|l|l|l|l|}
\hline Age & Gender & Diagnosis & Tongue & $\begin{array}{l}\text { Skin } \\
\text { involvement }\end{array}$ & Outcome & References \\
\hline 40 & $\mathrm{~F}$ & $\begin{array}{l}\text { T-cell } \\
\text { lymphoma }\end{array}$ & $\begin{array}{l}\text { ventrolateral } \\
\text { side }\end{array}$ & $\begin{array}{l}\text { left third } \\
\text { finger }\end{array}$ & alive & {$[10]$} \\
\hline 40 & M & $\begin{array}{l}\text { T-cell } \\
\text { lymphoma }\end{array}$ & dorsum & $\begin{array}{l}\text { finger right } \\
\text { foot }\end{array}$ & alive & {$[10]$} \\
\hline 72 & F & $\begin{array}{l}\text { Cutaneous } \\
\text { T-cell } \\
\text { lymphoma }\end{array}$ & dorsum & $\begin{array}{l}\text { trunk } \\
\text { extremities }\end{array}$ & $\begin{array}{l}12 \\
\text { months }\end{array}$ & {$[11]$} \\
\hline 85 & F & PCDLBCL & apex & thigh & $\begin{array}{l}11 \\
\text { months }\end{array}$ & $\begin{array}{l}\text { Our } \\
\text { case }\end{array}$ \\
\hline
\end{tabular}

PCDLBCL: Primary Cutaneous Diffuse Large B-Cell Lymphoma

Table 1: Cases of lymphoma with both tongue and cutaneous involvement. 
Citation: Kayukawa S, Kataoka T, Nishio T, Kanamori T, Kikuchi T, et al. (2014) Primary Cutaneous Diffuse Large B-Cell Lymphoma with Tongue Involvement. J Clin Case Rep 4: 339. doi:10.4172/2165-7920.1000339

radiotherapy. The relapsed tumor in the left inguinal region progressed more rapidly but, again, regressed in response to radiotherapy.

\section{References}

1. Swerdlov SH, Campo E, Harris NL (2008) World Health Organization (WHO) classification of tumors of hematopoietic and lymphoid tissues. Lyon, France: World Health Organization.

2. Willemze R, Jaffe ES, Burg G, Cerroni L, Berti E, et al. (2005) WHO-EORTC classification for cutaneous lymphomas. Blood 105: 3768-3785.

3. Sokol L, Naghashpour M, Glass LF (2012) Primary cutaneous B-cell lymphomas: recent advances in diagnosis and management. Cancer Control 19: $236-244$

4. Singh T, Amirtham U, Satheesh CT, Sajeevan KV, Jain A, et al. (2010) Primary B cell non-Hodgkin's lymphoma of tongue. Indian J Cancer 47: 84-86.

5. Guastafierro S, Falcone U, Celentano M, Cappabianca S, Giudice A, et al. (2008) Primary mantle-cell non-Hodgkin's lymphoma of the tongue. Int $\mathrm{J}$ Hematol 88: 206-208.

6. Terada T (2011) Primary non-Hodgkin B-cell lymphoma of the tongue. Br J Oral Maxillofac Surg 49: e18-19.

7. Goteri G, Ascani G, Filosa A, Rubini C, Olay S, et al. (2004) Primary malt lymphoma of the tongue. Med Oral Patol Oral Cir Bucal 9: 461-463.
8. Dey P, Luthra UK, Sheikh ZA, Mathews SB (1999) Fine needle aspiration cytology of primary non-Hodgkin's lymphoma of the tongue. A case report. Acta Cytol 43: 422-424.

9. Sato Y, Ohnishi N, Morito T, Takata K, Mizobuchi K, et al. (2009) Patients with localized primary non-tonsillar oral diffuse large B-cell lymphoma exhibit favorable prognosis despite a non-germinal center B-cell-like phenotype. Cancer Sci 100: 42-46.

10. May SA, Jones D, Medeiros LJ, Duvic M, Prieto VG, et al. (2007) Oral-cutaneous CD4-positive T-cell lymphoma: a study of two patients. Am J Dermatopathol 29: 62-67.

11. Quarterman MJ, Lesher JL Jr, Davis LS, Pantazis CG, Mullins S (1995) Rapidly progressive CD8-positive cutaneous T-cell lymphoma with tongue involvement. Am J Dermatopathol 17: 287-291.

12. Ferreri AJ, Campo E, Seymour JF, Willemze R, llariucci F, et al. (2004) Intravascular lymphoma: clinical presentation, natural history, management and prognostic factors in a series of 38 cases, with special emphasis on the cutaneous variant. $\mathrm{Br} \mathrm{J}$ Haematol 127: 173-183.

13. Murase T, Yamaguchi M, Suzuki R, Okamoto M, Sato $Y$, et al. (2007) Intravascular large B-cell lymphoma (IVLBCL): a clinicopathologic study of 96 cases with special reference to the immunophenotypic heterogeneity of CD5. Blood 109: 478-485. 